Bromfield S. M. (1953). J. gen. Microbiol. 8, 378-390.

\title{
Sulphate Reduction in Partially Sterilized Soil Exposed to Air
}

\author{
By S. M. BROMFIELD \\ Soil Microbiology Department, Rothamsted Experimental Station, \\ Harpenden, Hertfordshire
}

SUMMARY: $\mathrm{H}_{2} \mathrm{~S}$ was evolved from soil treated with $\mathrm{CCl}_{4}$ when moistened with sucrose and $\left(\mathrm{NH}_{4}\right)_{2} \mathrm{SO}_{4}$ solution and incubated aerobically. $\mathrm{H}_{2} \mathrm{~S}$ formation took place when the soil moisture was less than field capacity, and over a range of $\mathbf{p H}$ values from 5 to 8 . The organism responsible was isolated and identified as Bacillus megaterium. Several strains of this organism reduced sulphate in well-aerated sterilized soil and liquid media but not in soil or liquid incubated anaerobically.

The action of $\mathbf{C C l}_{4}$ in fresh soil is to check or destroy certain fungi and bacteria which normally inhibit sulphate reduction by $B$. megaterium. Some of these organisms were isolated and shown to be sensitive to $\mathrm{CCl}_{\mathbf{4}}$ and to inhibit sulphate reduction by B. megaterium in sterilized soil. The isolates did not exhibit antibiotic action when grown in certain defined media.

The reduction of sulphate in soil is known to be achieved by Desulphovibrio species, and although there have been reports of other micro-organisms able to reduce sulphate (Nadson, 1904; Nastukoff, 1895; Sawjalow, 1913; Shturm, 1948; Tanner, 1918), the widely held view is that only Desulphovibrio spp. have been shown with certainty to bring about this reduction (Bunker, 1936; Butlin, Adams \& Thomas, 1949; Starkey, 1950; Starkey \& Wight, 1945; Young, 1936).

Desulphovibrio spp. are obligate anaerobes and utilize sulphate and other inorganic sulphur compounds as specific hydrogen acceptors during the oxidation of organic energy sources (Baars, 1930). The sulphur compounds are reduced to sulphides. Shturm (1950) claims to have obtained growth of Desulphovibrio spp. under aerobic conditions in meat extract broth without added sulphates, but the reduction of sulphate under aerobic conditions has not been reported in the literature as far as is known to the author. The present author observed that soil after treatment with $\mathrm{CCl}_{4}$ released $\mathrm{H}_{2} \mathrm{~S}$ from sucrose + $\left(\mathrm{NH}_{4}\right)_{2} \mathrm{SO}_{4}$ solution under what appeared to be well-aerated conditions. When this observation is considered in the light of existing literature the problem arises of how sulphate reduction can occur under such conditions. This paper describes experiments to discover whether anaerobic conditions were developing in the apparently well-aerated soil, the nature of the micro-organisms responsible for the sulphate reduction and the effect of $\mathrm{CCl}_{4}$ on the process.

\section{METHODS}

The soils listed in Table 1 were crushed with pestle and mortar and passed through a nest of sieves of $3,2,1$ and $0.5 \mathrm{~mm}$. mesh. The particles remaining on the $3 \mathrm{~mm}$. mesh were discarded and the particles on the 2,1 and $0.5 \mathrm{~mm}$. mesh collected and kept separate. The size of the particles of soil referred to 
below are defined by the diameter of the mesh which held them back; thus soil composed of particles which will pass through $3 \mathrm{~mm}$. but not $2 \mathrm{~mm}$. holes is referred to as $2 \mathrm{~mm}$. soil.

Hydrogen sulphide evolution was detected with lead acetate paper. For pH determinations 5 or $10 \mathrm{~g}$. of soil were suspended in 12.5 or $25 \mathrm{ml}$. distilled water respectively and shaken 20 times every $\frac{1}{4} \mathrm{hr}$. during $2 \mathrm{hr}$., after which the $\mathrm{pH}$ value was obtained by means of a glass electrode. Soil was sterilized by autoclaving $5 \mathrm{~g}$. lots of dry sieved soil in $100 \mathrm{ml}$. conical flasks for $30 \mathrm{~min}$. at $20 \mathrm{lb} . / \mathrm{sq} . \mathrm{in}$.

\section{Culture media}

Sucrose $\left(\mathrm{NH}_{4}\right)_{2} \mathrm{SO}_{4}$ solution. Sucrose, 5.0 g.; $\left(\mathrm{NH}_{4}\right)_{2} \mathrm{SO}_{4}, 1.25 \mathrm{~g}$.; distilled water, $100 \mathrm{ml}$.; autoclaved $10 \mathrm{~min}$. at $10 \mathrm{lb}$./sq.in. This solution was only used for the Rothamsted soil and was usually applied in the proportion of $2 \mathrm{ml} . / 5 \mathrm{~g}$. soil. For other soils the amounts of sucrose and $\left(\mathrm{NH}_{4}\right)_{2} \mathrm{SO}_{4}$ in $100 \mathrm{ml}$. of water depended on the water-holding capacity of the soil.

Sulphate reduction medium (Baars, 1930). $\mathrm{K}_{2} \mathrm{HPO}_{4}, 0 \cdot 05 \mathrm{~g}$.; sodium lactate (70\% solution), 0.50 g.; $\mathrm{NH}_{4} \mathrm{Cl}, 0 \cdot 10$ g.; $\mathrm{CaSO}_{4}, 0 \cdot 10$ g.; $\mathrm{MgSO}_{4} .7 \mathrm{H}_{2} \mathrm{O}, 0 \cdot 20$ g.; $\mathrm{FeSO}_{4}\left(\mathrm{NH}_{4}\right)_{2} \mathrm{SO}_{4} .6 \mathrm{H}_{2} \mathrm{O}, 0.05 \mathrm{~g}$; tap water, $100 \mathrm{ml}$; $\mathrm{pH} \mathrm{7.2;} \mathrm{autoclaved}$ $15 \mathrm{~min}$. at $15 \mathrm{lb} . / \mathrm{sq} . \mathrm{in}$.

Czapek agar, modified. $\mathrm{NaNO}_{3}, 0.2 \mathrm{~g}$.; $\mathrm{KCl}, 0.05 \mathrm{~g} . ; \mathrm{MgSO}_{4} .7 \mathrm{H}_{2} \mathrm{O}, 0.05 \mathrm{~g}$; $\mathrm{FeSO}_{4} .7 \mathrm{H}_{2} \mathrm{O}, 0.001 \mathrm{~g}$; $\mathrm{KH}_{2} \mathrm{PO}_{4}, 0.1 \mathrm{~g}$. ; distilled water, $100 \mathrm{ml}$.; sucrose, 3.0 g.; agar, $2 \cdot 0$ g.; pH 4.2; autoclaved $10 \mathrm{~min}$. at $10 \mathrm{lb}$./sq.in.

Sucrose phosphate peptone agar (SPP). Sucrose, 0.5 g.; $\mathrm{K}_{2} \mathrm{HPO}_{4}, 0.5$ g.; Difco peptone, $0.5 \mathrm{~g}$.; distilled water, $100 \mathrm{ml}$.; agar 2.0 g.; pH 7.5; autoclaved $15 \mathrm{~min}$. at $15 \mathrm{lb}$./sq.in.

Medium $(M)$ for $\mathrm{H}_{2} \mathrm{~S}$ evolution by Bacillus megaterium. $\mathrm{KH}_{2} \mathrm{PO}_{4}, 0.5 \mathrm{~g}$.; $\mathrm{NaCl}, 0.02$ g.; $\mathrm{CaCl}_{2}, 0.01$ g.; $\left(\mathrm{NH}_{4}\right)_{2} \mathrm{SO}_{4}, 1 \cdot 25$ g.; sucrose, 5.0 g.; distilled water, $100 \mathrm{ml}$.; Difco yeast extract, 0.3 g.; $\mathrm{CaCO}_{3}, 0 \cdot 1 \mathrm{~g}$.; $\mathrm{pH} 6.5$; autoclaved $15 \mathrm{~min}$. at $15 \mathrm{lb} . / \mathrm{sq}$. in.

Medium for testing antagonisms. Sucrose, $1.0 \mathrm{~g}$.; $\left(\mathrm{NH}_{4}\right)_{2} \mathrm{SO}_{4}, 0 \cdot 2 \mathrm{~g}$.; Difco yeast extract, $0.05 \mathrm{~g}$.; $\mathrm{KH}_{2} \mathrm{PO}_{4}, 0.05 \mathrm{~g}$. $; \mathrm{MgSO}_{4} .7 \mathrm{H}_{2} \mathrm{O}, 0.02 \mathrm{~g}$.; distilled water, $100 \mathrm{ml}$.; agar, 2.0 g.; pH 6.5; autoclaved $15 \mathrm{~min}$. at $10 \mathrm{lb}$./sq.in.

\section{RESULTS}

\section{Conditions under which $\mathrm{H}_{2} \mathrm{~S}$ evolution occurs in $\mathrm{CCl}_{4}$-treated soil}

The effect of sucrose and $\left(\mathrm{NH}_{4}\right)_{2} \mathrm{SO}_{4}$ concentration on the evolution of $\mathrm{H}_{2} \mathrm{~S}$. Ten g. samples of $1 \mathrm{~mm}$. mesh Rothamsted soil were spread evenly over the bottom of $100 \mathrm{ml}$. conical flasks. Duplicate flasks received the following amounts of sucrose and $\left(\mathrm{NH}_{4}\right)_{2} \mathrm{SO}_{4}$ made up in $3.6 \mathrm{ml}$. distilled water:

$$
\begin{array}{lllll}
\left(\mathrm{NH}_{4}\right)_{2} \mathrm{SO}_{4} & 0.05 \mathrm{~g} . & 0.025 \mathrm{~g} . & 0.005 \mathrm{~g} . & 0.0025 \mathrm{~g} . \\
\text { Sucrose } & 0.2 \mathrm{~g} . & 0.1 \mathrm{~g} . & 0.02 \mathrm{~g} . & 0.01 \mathrm{~g} .
\end{array}
$$

All the eight flasks then received $1 \mathrm{ml} . \mathrm{CCl}_{4}$ and strips of lead acetate paper were hung in the flasks to within $1 \mathrm{~cm}$. of the soil surface. After 7 days' incubation at $30^{\circ} \mathrm{H}_{2} \mathrm{~S}$ was detected in all flasks except those containing $0.01 \mathrm{~g}$. sucrose and $0.0025 \mathrm{~g}$. $\left(\mathrm{NH}_{4}\right)_{2} \mathrm{SO}_{4}$. 
By keeping the sucrose at $\mathbf{0 . 2} \mathrm{g}$./flask and adding concentrations of $\left(\mathrm{NH}_{4}\right)_{2} \mathrm{SO}_{4}$ decreasing from $0.05 \mathrm{~g}$. $/ 10 \mathrm{~g}$. soil to zero, it was found that $\mathrm{H}_{2} \mathrm{~S}$ was evolved from all cultures except those to which no $\left(\mathrm{NH}_{4}\right)_{2} \mathrm{SO}_{4}$ was added. Similarly, by keeping the $\left(\mathrm{NH}_{4}\right)_{2} \mathrm{SO}_{4}$ at $0.05 \mathrm{~g}$. and adding sucrose in concentrations ranging from $0 \cdot 2 \mathrm{~g} . / 10 \mathrm{~g}$. soil to zero, $\mathrm{H}_{2} \mathrm{~S}$ was evolved from all flasks except those containing no added sucrose. When the $\left(\mathrm{NH}_{4}\right)_{2} \mathrm{SO}_{4}$ was replaced by $\mathrm{NH}_{4} \mathrm{Cl}$, no $\mathrm{H}_{2} \mathrm{~S}$ was evolved. This result, together with the observation that no $\mathrm{H}_{2} \mathrm{~S}$ appeared when $\left(\mathrm{NH}_{4}\right)_{2} \mathrm{SO}_{4}$ was omitted, indicated that the sulphur in the $\mathrm{H}_{2} \mathrm{~S}$ came from the sulphate. An experiment described later supports this view.

Effect of soil type. To observe the effect of soil type on $\mathrm{H}_{2} \mathrm{~S}$ evolution, soils differing in texture and $\mathrm{pH}$ value were treated as follows: duplicate $10 \mathrm{~g}$. samples of $1 \mathrm{~mm}$. soil particles were spread evenly over the bottom of $100 \mathrm{ml}$. conical flasks and each was given $0 \cdot 2 \mathrm{~g}$. sucrose and $0.05 \mathrm{~g}$. $\left(\mathrm{NH}_{4}\right)_{2} \mathrm{SO}_{4}$ in aqueous solution. The actual volume and hence the strength of the solution added varied with the soil. Each flask was then treated with $1 \mathrm{ml}$. of $\mathrm{CCl}_{4}$. The texture, amount of solution added, the evolution of $\mathbf{H}_{2} \mathrm{~S}$ and the initial and final $\mathrm{pH}$ of the soils after 7 days' incubation at $30^{\circ}$, are given in Table 1. The Old Kennington and Rothamsted soils showed marked evolution of $\mathbf{H}_{2} \mathrm{~S}$, Bones Close and Harpenden Common a trace, and Derby and Exton Park soils none.

Table 1. Changes in $\mathrm{pH}$ values and presence of $\mathrm{H}_{2} \mathrm{~S}$ evolution from various soils moistened with sucrose + ammonium sulphate solution

Incubation for 7 days at $30^{\circ}$.

\begin{tabular}{|c|c|c|c|c|c|c|c|}
\hline \multirow[b]{2}{*}{ Soil } & \multicolumn{5}{|c|}{ Incubation for 7 days at $30^{\circ}$. } & \multicolumn{2}{|c|}{$\begin{array}{c}\mathbf{H}_{2} \mathrm{~S} \text { produced }(+) \\
\text { or not }(-)\end{array}$} \\
\hline & Texture & $\begin{array}{l}\text { Volume } \\
\text { of } \\
\text { solution } \\
\text { added } \\
\text { (ml.) }\end{array}$ & $\begin{array}{c}\text { Initial } \\
\text { pH } \\
\text { value }\end{array}$ & $\begin{array}{c}\text { Control } \\
\text { soil }\end{array}$ & $\begin{array}{c}\text { Soil } \\
\text { treated } \\
\text { with } \\
\mathrm{CCl}_{4}\end{array}$ & $\begin{array}{l}\text { Control } \\
\text { soil }\end{array}$ & $\begin{array}{c}\text { Soil } \\
\text { treated } \\
\text { with } \\
\mathrm{CCl}_{4}\end{array}$ \\
\hline $\begin{array}{l}\text { Old Kennington, } \\
\text { Berks. }\end{array}$ & Sandy clay & 2 & $6 \cdot 3$ & $5 \cdot 7$ & $6 \cdot 4$ & + & + \\
\hline Rothamsted, Herts. & Clay & 4 & $6 \cdot 5$ & $6 \cdot 8$ & $6 \cdot 5$ & - & + \\
\hline $\begin{array}{l}\text { Bones Close, } \\
\quad \text { Rothamsted, Herts. }\end{array}$ & Clay & 4 & $7 \cdot 0$ & $7 \cdot 0$ & $7 \cdot 0$ & - & \pm \\
\hline $\begin{array}{l}\text { Harpenden Common, } \\
\text { Herts. }\end{array}$ & Clay & $\mathbf{3 \cdot 5}$ & $4 \cdot 0$ & 3.5 & $3 \cdot 4$ & - & \pm \\
\hline $\begin{array}{l}\text { Exton Park, } \\
\text { Rutland }\end{array}$ & Clay & 4 & $7 \cdot 2$ & $7 \cdot 1$ & $7 \cdot 2$ & - & - \\
\hline Derby & Sandy loam & $\mathbf{3}$ & $4 \cdot 8$ & $4 \cdot 7$ & $4 \cdot 3$ & - & - \\
\hline
\end{tabular}

Effect of $\mathrm{pH}$ value. To find the $\mathrm{pH}$ range at which $\mathrm{H}_{2} \mathrm{~S}$ was evolved from Rothamsted soil $1 \mathrm{ml}$. distilled water and $\mathbf{0} \cdot 25-2 \cdot 0 \mathrm{ml}$. of $\mathrm{N}-\mathrm{HCl}$ or $\mathrm{N}-\mathrm{NaOH}$ were added to duplicate $5 \mathrm{~g}$. samples of soil. The soil samples were allowed to dry at $40^{\circ}$ for $48 \mathrm{hr}$. and then treated with sucrose $+\left(\mathrm{NH}_{4}\right)_{2} \mathrm{SO}_{4}$ solution and $\mathrm{CCl}_{4}$. After 4 days' incubation at $30^{\circ}$ the evolution of $\mathrm{H}_{2} \mathrm{~S}$ was noted and $\mathrm{pH}$ determinations made on the soils. Hydrogen sulphide was evolved between $\mathrm{pH} 5 \cdot 0$ and $7 \cdot 7$ and was greatest between $\mathrm{pH} 5 \cdot 5$ and $7 \cdot 0$. From the results of this and the previous experiment it was difficult to see why $\mathrm{H}_{2} \mathrm{~S}$ should not be 
produced in Exton Park soil and to a greater degree in Bones Close soil. It was realized that factors affecting $\mathrm{H}_{2} \mathrm{~S}$ evolution could be different from those affecting sulphide formation, and that the $\mathrm{H}_{2} \mathrm{~S}$ once produced might form a non-volatile sulphide.

Effect of $\mathrm{CaCO}_{3}$. It was noticed that Exton Park and Bones Close soils contained visible amounts of $\mathrm{CaCO}_{3}$ and that Rothamsted and Old Kennington soils did not. To see what effect this $\mathrm{CaCO}_{3}$ might have on the evolution of $\mathrm{H}_{2} \mathrm{~S}$ from Rothamsted soil, increasing quantities of $\mathrm{CaCO}_{3}$ were added to duplicate $5 \mathrm{~g}$. soil samples; the soils were then treated with sucrose $+\left(\mathrm{NH}_{4}\right)_{2} \mathrm{SO}_{4}$ solution and $\mathrm{CCl}_{4}$, incubated for 4 days at $30^{\circ}$ and then examined for $\mathrm{H}_{2} \mathrm{~S}$ evolution and their $\mathrm{pH}$ values determined. As little as $0.05 \mathrm{~g} . \mathrm{CaCO}_{3} / 5 \mathrm{~g}$. soil decreased the evolution of $\mathrm{H}_{2} \mathrm{~S}$ and $\mathbf{0 . 2} \mathrm{g}$. prevented it; the $\mathrm{pH}$ values of the treated soils were between $7 \cdot 0$ and $7 \cdot 5$.

To see whether sulphide was present in the soils receiving $0 \cdot 2,0 \cdot 3$ and $0 \cdot 5 \mathrm{~g}$. $\mathrm{CaCO}_{3}$ the suspensions used for $\mathrm{pH}$ determinations were acidified with concentrated $\mathrm{H}_{2} \mathrm{SO}_{4}$, and in all cases sufficient $\mathrm{H}_{2} \mathrm{~S}$ was released to darken lead acetate paper. Soils which did not receive sucrose $+\left(\mathrm{NH}_{4}\right)_{2} \mathrm{SO}_{4}$ solution did not give a positive test for $\mathrm{H}_{2} \mathrm{~S}$ on acidification. To see whether $\mathrm{H}_{2} \mathrm{~S}$ evolution could be obtained from Exton Park soil, $1.5 \mathrm{ml}$. $2 \mathrm{~N}-\mathrm{HCl}$ was added to $5 \mathrm{~g}$. of the soil to decrease the amount of $\mathrm{CaCO}_{3}$, the soil allowed to dry at $40^{\circ}$ and then sucrose $+\left(\mathrm{NH}_{4}\right)_{2} \mathrm{SO}_{4}$ solution and $\mathrm{CCl}_{4}$ applied; after 4 days at $30^{\circ}, \mathrm{H}_{2} \mathrm{~S}$ was evolved.

The effect of soil particle size, moisture content and amount of soil. The effect of particle size on $\mathrm{H}_{2} \mathrm{~S}$ evolution was studied by spreading evenly duplicate 5 g. samples of 2,1 and $0.5 \mathrm{~mm}$. mesh Rothamsted soil over the bottoms of $100 \mathrm{ml}$. conical flasks and treating them with sucrose $+\left(\mathrm{NH}_{4}\right)_{2} \mathrm{SO}_{4}$ solution and $\mathrm{CCl}_{4} \cdot \mathrm{H}_{2} \mathrm{~S}$ was evolved in all flasks after 4 days at $30^{\circ}$.

The effect of moisture content was studied as follows. To duplicate $10 \mathrm{~g}$. samples of air-dried $1 \mathrm{~mm}$. mesh with Rothamsted soil in $100 \mathrm{ml}$. conical flasks, increasing volumes from 0.5 to $8.0 \mathrm{ml}$. of sucrose $+\left(\mathrm{NH}_{4}\right)_{2} \mathrm{SO}_{4}$ solution were added. This experiment did not test the effect of moisture content alone, as the quantities of sucrose and $\left(\mathrm{NH}_{4}\right)_{2} \mathrm{SO}_{4}$ also varied. However, even in $0.5 \mathrm{ml}$. of the sucrose $+\left(\mathrm{NH}_{4}\right)_{2} \mathrm{SO}_{4}$ solution, there was $0.05 \mathrm{~g}$. sucrose and $0.006 \mathrm{~g}$. $\left(\mathrm{NH}_{4}\right)_{2} \mathrm{SO}_{4}$ which, from the experiment recorded above, was sufficient to allow $\mathrm{H}_{2} \mathrm{~S}$ evolution.

The soils which received from 0.5 to $2 \cdot 0 \mathrm{ml}$. of solution were shaken to mix the wet and dry soil thoroughly, and then all soils received $\mathrm{CCl}_{4} \cdot \mathrm{H}_{2} \mathrm{~S}$ was evolved from all soils except those which received $0.5,0.75$ and $8.0 \mathrm{ml}$. of solution. The air-dried soil contained $2.5 \%$ moisture, and the soil when at field capacity contained $25 \%$ moisture. $\mathrm{H}_{2} \mathrm{~S}$ was evolved from Rothamsted soil which contained as little as $\mathbf{1 2 . 5} \%$ moisture.

The effect of varying the amount of soil per flask was studied by spreading evenly $1 \mathrm{~mm}$. mesh Rothamsted soil in duplicate amounts of 1-20 g. over the bottoms of $250 \mathrm{ml}$. conical flasks. The soils were moistened with sucrose + $\left(\mathrm{NH}_{4}\right)_{2} \mathrm{SO}_{4}$ solution in the proportion $0.4 \mathrm{ml}$./g. soil and then treated with $1.0 \mathrm{ml}$. of $\mathrm{CCl}_{4} \cdot \mathrm{H}_{2} \mathrm{~S}$ was detected in all flasks after 4 days at $30^{\circ}$. 


\section{Organisms responsible for sulphate reduction}

An examination of the microflora in soil after treatment with $\mathrm{CCl}_{4}$. It was possible that the $\mathrm{CCl}_{4}$ may have stimulated the sulphate-reducing bacteria (Desulphovibrio spp.). To ascertain whether this were so, soil treated with sucrose $+\left(\mathrm{NH}_{4}\right)_{2} \mathrm{SO}_{4}$ solution and $\mathrm{CCl}_{4}$, and soil treated with sucrose + $\left(\mathrm{NH}_{4}\right)_{2} \mathrm{SO}_{4}$ solution only, were incubated until $\mathrm{H}_{2} \mathrm{~S}$ was detected in the $\mathrm{CCl}_{4}$ treated soil ( 2 days at $30^{\circ}$ ), after which time serial dilutions from $1 / 10$ to $1 / 10^{7}$ of both soils were made in sterile water. Baars's sulphate reduction medium in test tubes and as agar plates was inoculated with $1 \mathrm{ml}$. of each of the dilutions and incubated under hydrogen in anaerobic jars for 10 days at $30^{\circ}$. With either soil treatment $\mathrm{H}_{2} \mathrm{~S}$ was found in liquid medium only when given 1/10 dilution of the soil.

To obtain some indication of the qualitative effect of $\mathrm{CCl}_{4}$ on the microflora the following experiment was conducted. Two $10 \mathrm{~g}$. samples of soil were each moistened with $4 \mathrm{ml}$. sucrose $+\left(\mathrm{NH}_{4}\right)_{2} \mathrm{SO}_{4}$ solution, and one soil sample received in addition $1 \mathrm{ml}$. $\mathrm{CCl}_{4}$. They were incubated at $30^{\circ}$ for $48 \mathrm{hr}$. and $\mathrm{H}_{2} \mathrm{~S}$ appeared in the $\mathrm{CCl}_{4}$-treated soil after this time. To each soil sample $100 \mathrm{ml}$. steriledistilled water was added and the samples shaken 100 times, allowed to stand for $10 \mathrm{~min}$. and then shaken another 100 times. Serial dilutions up to $1 / 10^{7}$ were made from each suspension. The second shaking after $10 \mathrm{~min}$. was necessary because the soil which did not receive $\mathrm{CCl}_{\mathbf{4}}$ was difficult to wet and remained in clumps bound by fungal growth after the first shaking. One $\mathrm{ml}$. of dilutions of each soil sample were pipetted aseptically into sterile Petri dishes and mixed with melted (45 $)$ sterile Czapek agar or SPP agar. The SPP agar plates were incubated aerobically and anaerobically at $30^{\circ}$ and the Czapek plates aerobically at $30^{\circ}$. A general description of the growth developing on these plates is given below. Platings from the $\mathrm{CCl}_{4}$-treated soil showed no fungi, few iridescent bacterial colonies and many white opaque colonies on the aerobic plates, and very little growth or gas formation on the anaerobic plates. Platings from the untreated soil showed abundant fungi, iridescent and opaque bacterial colonies on the aerobic plates. Iridescent and opaque colonies also appeared on the anaerobic plates and were accompanied by abundant gas formation.

To determine whether the organisms responsible for the $\mathrm{H}_{2} \mathrm{~S}$ evolution from the $\mathrm{CCl}_{4}$-treated soil were developing on these two media, loopfuls of growth from various aerobic plates were suspended in sucrose $+\left(\mathrm{NH}_{4}\right)_{2} \mathrm{SO}_{4}$ solution, and $2 \mathrm{ml}$. of each of these suspensions were used to inoculate duplicate $5 \mathrm{~g}$. samples of sterile Rothamsted soil. Two soil samples in duplicate were inoculated from each suspension, and one of these soil samples also received $1 \mathrm{ml}$. $\mathrm{CCl}_{4}$. The results after aerobic incubation are given in Table 2.

$\mathrm{H}_{2} \mathrm{~S}$ was evolved from sterile soil inoculated with organisms from plates which received dilutions of $\mathrm{CCl}_{4}$-treated soil, irrespective of whether the inoculated soil received $\mathrm{CCl}_{4}$ or not. The addition of $\mathrm{CCl}_{4}$ delayed the appearance of $\mathrm{H}_{2} \mathrm{~S}$ by $24 \mathrm{hr}$. Sterile soil inoculated with the organisms from plates which received dilutions of untreated soil only showed strong evolution of $\mathrm{H}_{2} \mathrm{~S}$ when 
the soil received $\mathrm{CCl}_{4}$. In the absence of $\mathrm{CCl}_{4}$ these soils had a mat of fungal mycelia over their surfaces and gave only a slight trace of $\mathbf{H}_{2} \mathrm{~S}$.

Thus the organisms responsible for $\mathrm{H}_{2} \mathrm{~S}$ evolution and the organisms which inhibit $\mathrm{H}_{2} \mathrm{~S}$ evolution both developed on these media; $\mathrm{CCl}_{4}$ destroyed inhibitory organisms, which may be fungi or $\mathrm{CCl}_{4}$-sensitive bacteria.

Table 2. Hydrogen sulphide production from sterilized Rothamsted soil moistened with sucrose + ammonium sulphate solution, + or $-\mathrm{CCl}_{4}$, and inoculated with organisms from various plates as shown below

Part 2

Sterile Rothamsted soil and nutrients + or $-\mathrm{CCl}_{4}$

Part 1

Source of inocula for Part 2

\begin{tabular}{|c|c|c|c|c|c|c|}
\hline \multirow{3}{*}{$\begin{array}{c}\text { Soil and sucrose }+ \\
\left(\mathrm{NH}_{4}\right)_{2} \mathrm{SO}_{4} \text { solution with } \\
(+) \text { or without }(-) \\
\mathrm{CCl}_{4} ; 3^{\circ} \text { for } 48 \mathrm{hr} .\end{array}$} & \multirow{3}{*}{$\begin{array}{c}\text { Suspension } \\
\text { dilution } \\
\text { (reciprocal) }\end{array}$} & \multirow{3}{*}{$\begin{array}{c}\text { Medium } \\
\text { plates on } 30^{\circ} \\
\text { aerobic }\end{array}$} & \multicolumn{4}{|c|}{ Part 1 aerobic, $30^{\circ}(\mathrm{hr})}$. \\
\hline & & & 24 & 48 & 24 & 48 \\
\hline & & & \multicolumn{4}{|c|}{$\mathbf{H}_{2} \mathrm{~S}$ production $(+$ or - ) } \\
\hline+ & $10^{4}$ & Czapek & + & + & - & + \\
\hline+ & $10^{5}$ & Czapek & + & + & - & + \\
\hline+ & $10^{5}$ & SPP & + & + & - & + \\
\hline+ & $10^{6}$ & SPP & + & + & - & + \\
\hline- & $10^{4}$ & Czapek & $-\mathbf{F}$ & $-\mathbf{F}$ & - & \pm \\
\hline- & $10^{5}$ & Czapek & $-\mathbf{F}$ & $-\mathbf{F}$ & - & $\overline{ \pm}$ \\
\hline - & $10^{5}$ & SPP & $-\mathbf{F}$ & $-\mathbf{F}$ & - & $\dot{t}$ \\
\hline- & $10^{6}$ & SPP & - & - & - & + \\
\hline & $\mathrm{F}=$ funga $]$ & on soil sur & & & & \\
\hline
\end{tabular}

Isolation and identification of the $\mathrm{H}_{2} \mathrm{~S}$-producing micro-organisms. From previous experiments it was found that the organism which produced $\mathrm{H}_{2} \mathrm{~S}$ grew aerobically at $30^{\circ}$ on SPP agar and survived $\mathrm{CCl}_{4}$ treatment. Enrichment cultures were obtained in the following manner: $5 \mathrm{~g}$. fresh Rothamsted soil were treated with $1 \mathrm{ml}$. $\mathrm{CCl}_{4}$ and moistened with $2 \mathrm{ml}$. sucrose $+\left(\mathrm{NH}_{4}\right)_{2} \mathrm{SO}_{4}$ solution. The mixture was incubated at $30^{\circ}$ for 3 days, suspended in $20 \mathrm{ml}$. sterile-distilled water and a loopful of the suspension plated on SPP agar. After $48 \mathrm{hr}$. at $30^{\circ}$ a loopful of growth from the plate was suspended in $2 \mathrm{ml}$. sucrose $+\left(\mathrm{NH}_{4}\right)_{2} \mathrm{SO}_{4}$ solution and added to $5 \mathrm{~g}$. sterile Rothamsted soil. The inoculated soil was treated with $1 \mathrm{ml}$. $\mathrm{CCl}_{4}$ and incubated until $\mathrm{H}_{2} \mathrm{~S}$ was evolved. The re-inoculation procedure was repeated three times and from the plating of the suspension from the final enrichment flask, single colonies of different characteristics were picked off and were replated on SPP agar to test purity. Suspensions of these isolates in sucrose $+\left(\mathrm{NH}_{4}\right)_{2} \mathrm{SO}_{4}$ solution were used to inoculate samples of sterile soil with and without $\mathrm{CCl}_{4}$. Of five isolates tested two produced $\mathrm{H}_{2} \mathrm{~S}$. In soil cultures of these two isolates the evolution of $\mathrm{H}_{2} \mathrm{~S}$ appeared $24 \mathrm{hr}$. later when $\mathrm{CCl}_{4}$ was added.

Identification of the isolates. The two organisms were similar in biochemical reactions. One was identified as Bacillus megaterium (Smith, Gordon \& Clark, 1946). 
Ten strains of $B$. megaterium, nos. 7851, 2605, 2607, 5635, 5636, 5637, 6007, $6095,6347,6005,6094$; two of $B$. cereus, nos. 8035, 7587, and two of B. mycoides, nos. 926, 7586, were obtained from the National Collection of Type Cultures. The ability of each of these strains to produce sulphide from $\left(\mathrm{NH}_{4}\right)_{2} \mathrm{SO}_{4}$ was tested on sterile soil. The soil was moistened with a suspension of each strain in sucrose $+\left(\mathrm{NH}_{4}\right)_{2} \mathrm{SO}_{4}$ solution, incubated at $30^{\circ}$ and tested for $\mathrm{H}_{2} \mathrm{~S}$ evolution. $\mathrm{H}_{2} \mathrm{~S}$ was evolved from soil inoculated with all strains of $\boldsymbol{B}$. megaterium but not from soil inoculated with the $B$. cereus or $B$. mycoides strains.

\section{Experiments with pure cultures of Bacillus megaterium}

Reduction of sulphate. An experiment was made to see whether the sulphur of the $\mathrm{H}_{2} \mathrm{~S}$ originated from the added sulphate. Radioactive sulphur as $\left(\mathrm{NH}_{4}\right)_{2}{ }^{35} \mathrm{SO}_{4}$ was added to the sucrose $+\left(\mathrm{NH}_{4}\right)_{2} \mathrm{SO}_{4}$ solution so that $2 \mathrm{ml}$. of solution contained $5 \mu \mathrm{c}$. of ${ }^{35} \mathrm{~S}$. The solution was autoclaved, inoculated with B. megaterium and $2 \mathrm{ml}$. of it added to triplicate $5 \mathrm{~g}$. samples of sterile Rothamsted soil contained in wide-mouthed $100 \mathrm{ml}$. conical flasks. The lead acetate paper which collected the radioactive $\mathrm{H}_{2} \mathrm{~S}$ was in the form of a $1.5 \mathrm{~cm}$. diam. disk with a thin strip $6 \mathrm{~cm}$. long projecting from it. The strip of paper was inserted into a piece of glass tubing so that the disk of paper protruded from one end of the tube. The other end of the tube was wrapped centrally inside a cotton-wool plug. The moist lead acetate paper when mounted in this way could be inserted and withdrawn without touching the inside of the flask and thereby avoided possible contamination of the paper with radioactive sulphate. The flasks were incubated for $24 \mathrm{hr}$. at $30^{\circ}$. The disks of lead acetate paper were completely black after this period.

The disks were removed, dried and then counted; the mean count rates were 993, 960 and 628 counts/min. To obtain some indication of the amount of sulphide trapped by the lead acetate paper, disks of filter-paper were moistened with $0.015,0.02$ and $0.05 \mathrm{ml}$. of the $5 \mu \mathrm{c} .{ }^{35} \mathrm{~S}$ solution, dried and counted. The mean count rates were 1004, 1367 and 2727 counts/min. respectively. The count rate of the lead sulphide disks approximated to that of $0.015 \mathrm{ml}$. of original solution which thus represented nearly $0.75 \%$ of the added ${ }^{35} \mathrm{~S}$.

The effect of calcium carbonate, soil $\mathrm{pH}$ value and low moisture content on hydrogen sulphide evolution. The experiments on the effect of $\mathrm{CaCO}_{3}, \mathrm{pH}$ value and moisture content on $\mathrm{H}_{2} \mathrm{~S}$ evolution, from unsterile soil treated with $\mathrm{CCl}_{4}$ and sucrose $+\left(\mathrm{NH}_{4}\right)_{2} \mathrm{SO}_{4}$ solution, were repeated on sterile Rothamsted soil inoculated with a suspension of $B$. megaterium in sucrose $+\left(\mathrm{NH}_{4}\right)_{2} \mathrm{SO}_{4}$ solution; 0.05 g. added $\mathrm{CaCO}_{3} / 5$ g. soil greatly decreased the amount of $\mathrm{H}_{2} \mathrm{~S}$ evolved, and $0.2 \mathrm{~g} \cdot \mathrm{CaCO}_{3} / 5 \mathrm{~g}$. soil prevented it. When these cultures were acidified with $\mathrm{H}_{2} \mathrm{SO}_{4}, \mathrm{H}_{2} \mathrm{~S}$ was released in sufficient amounts to darken lead acetate paper. The pure culture of $B$. megaterium evolved $\mathrm{H}_{2} \mathrm{~S}$ from sterile soil at $\mathrm{pH}$ values between 5 and 8 and gave the greatest evolution between $\mathrm{pH} 5.5$ and 7.0. Hydrogen sulphide was evolved from $10 \mathrm{~g}$. sterilized soil moistened with as little as $1 \mathrm{ml}$. sucrose $+\left(\mathrm{NH}_{4}\right)_{2} \mathrm{SO}_{4}$ solution and inoculated with $B$. megaterium. These results are in agreement with those obtained earlier with the $\mathrm{CCl}_{4}$-treated fresh soil. 
Reduction of sulphate in soils of high moisture content. The evolution of $\mathrm{H}_{2} \mathrm{~S}$ was studied in soils of high moisture content. Duplicate $10 \mathrm{~g}$. samples of sterile Rothamsted soil in $100 \mathrm{ml}$. conical flasks were moistened with $5 \mathrm{ml}$. B. megaterium suspension in sucrose $+\left(\mathrm{NH}_{4}\right)_{2} \mathrm{SO}_{4}$ solution, and also received 1-5 ml. sterile distilled water; another set of $10 \mathrm{~g}$. samples of Rothamsted soil received $10-20 \mathrm{ml}$. of the $B$. megaterium suspension; a final set received $10 \mathrm{ml}$. suspension and $10 \mathrm{ml}$. sterile distilled water.

The soils which received $6-10 \mathrm{ml}$. of liquid were completely saturated but had soil crumbs projecting above the surface of the solution; those which received 15 and $20 \mathrm{ml}$. had depths of 2-3 and 4-5 mm., respectively, of liquid above the soil.

$\mathrm{H}_{2} \mathrm{~S}$ was evolved in sufficient amounts to blacken lead acetate paper completely from all flasks except those in which the soil was completely submerged. In the latter the edges of the lead acetate paper only turned a faint brown. There was no increase in the colour of the lead acetate paper after acidification of the cultures in these flasks.

Reduction of sulphate in liquid media. An attempt was made to obtain $\mathrm{H}_{2} \mathrm{~S}$ evolution from liquid media. The media were dispensed in duplicate $3 \mathrm{ml}$. lots in $100 \mathrm{ml}$. conical flasks, and a strip of lead acetate paper was suspended in each flask. One drop of a suspension of a $48 \mathrm{hr}$. SPP agar slope culture of B. megaterium was added to each flask and the contents incubated aerobically or anaerobically for 4 days at $30^{\circ}$. A number of different media were tested and only medium $\mathrm{M}$ was found to give $\mathrm{H}_{2} \mathrm{~S}$ evolution under aerobic incubation. No $\mathrm{H}_{2} \mathrm{~S}$ was evolved when Difco yeast extract was omitted or replaced by amino-acids or when $\left(\mathrm{NH}_{4}\right)_{2} \mathrm{SO}_{4}$ was replaced by $\mathrm{NH}_{4} \mathrm{Cl}$. Baars's medium was unsuitable for sulphate reduction by this organism.

Aeration experiments. Sterile Rothamsted soil was inoculated with a suspension of $B$. megaterium in sucrose $+\left(\mathrm{NH}_{4}\right)_{2} \mathrm{SO}_{4}$ solution and incubated: (a) anaerobically for 7 days under hydrogen in a McIntosh \& Fildes jar; (b) aerobically (1) in a conical flask stoppered with a cotton-wool plug, (2) in a conical flask with a stream of water-washed air blowing on to the surface of the soil, (3) in a glass tube in which a layer of soil $1 \mathrm{~cm}$. thick was supported on glass-wool half-way up the tube and water-washed air was passed through it from below. The water-washing of the air was to remove dust and to minimize evaporation from the soil. The air was delivered from an aquarium aeration pump at a rate of $100 \mathrm{ml} . / \mathrm{min}$. The soil which was incubated anaerobically for 7 days did not release $\mathrm{H}_{2} \mathrm{~S}$ but did so when subsequently incubated aerobically for another 2 days. With the three aeration treatments enough $\mathrm{H}_{2} \mathrm{~S}$ was released completely to blacken the lead acetate papers.

B. megaterium was plated on SPP agar and incubated aerobically or anaerobically. The anaerobic plates showed no growth whilst the aerobic plates showed abundant growth; the anaerobic plates developed abundant growth after a further $\mathbf{2 4} \mathrm{hr}$. aerobic incubation. To test for the presence of Desulphovibrio spp. as contaminants in the 'sterilized' soil and $B$. megaterium culture, sterilized soil and fresh soil were moistened with sterile Baars's medium and with Baars's medium inoculated with $B$. megaterium. The soils were incubated 
aerobically and anaerobically for 10 days at $30^{\circ} \cdot \mathrm{H}_{2} \mathrm{~S}$ was evolved only from the anaerobic fresh soil, which indicated that both the sterilized soil and the culture were free from Desulphovibrio spp.

\section{The effect of carbon tetrachloride on the evolution of hydrogen sulphide from soils}

Comparison with other volatile substances. Duplicate $5 \mathrm{~g}$. samples of Rothamsted soil were treated with $2 \mathrm{ml}$. of one of the following substances : diethylether, $\mathrm{CCl}_{4}$, chloroform, toluene, xylene, $95 \%(\mathrm{v} / \mathrm{v})$ ethanol, benzene; or with $0.8 \mathrm{ml}$. of $2 \%(\mathrm{v} / \mathrm{v})$ phenol or $40 \%$ formalin. $\mathrm{H}_{2} \mathrm{~S}$ was evolved from those soils treated with ether, $\mathrm{CCl}_{4}$, chloroform or benzene. Similar experiments were repeated, but instead of using equal volumes of the volatile compounds the volumes used were the same as those lost by evaporation after $24 \mathrm{hr}$. These volumes were estimated by measuring changes in volume due to evaporation from a free surface $1 \mathrm{in}$. in diameter at hourly intervals. In this case the soils treated with ether, $\mathrm{CCl}_{4}$, chloroform, toluene, xylene or benzene all produced an increase in $\mathrm{H}_{2} \mathrm{~S}$ evolution. A further attempt was made to get a similar effect with formalin, ethanol and phenol. Duplicate $5 \mathrm{~g}$. samples of air-dried Rothamsted soil in Petri dishes were treated with $1 \mathrm{ml}$. of $1 \%$ formalin, $2 \%$ $(\mathrm{v} / \mathrm{v})$ phenol or $95 \%$ ethanol, or subjected to the vapours from filter-paper moistened with $0.1 \mathrm{ml} .40 \%$ formalin. The soils remained open to the air until the ethanol and formalin could not be detected by smell and until the phenoltreated soil was air dry. The soils were then moistened with sucrose $+\left(\mathrm{NH}_{4}\right)_{2} \mathrm{SO}_{4}$ solution and tested for $\mathrm{H}_{2} \mathrm{~S}$. Only the ethanol-treated soils evolved $\mathrm{H}_{2} \mathrm{~S}$ on incubation.

To determine whether $\mathrm{H}_{2} \mathrm{~S}$ was evolved while $\mathrm{CCl}_{4}$ was present or only after it had evaporated, three sets of flasks in duplicate containing $5 \mathrm{~g}$. Rothamsted soil were treated with sucrose $+\left(\mathrm{NH}_{4}\right)_{2} \mathrm{SO}_{4}$ solution and $2 \mathrm{ml}$. $\mathrm{CCl}_{4}$. The first set received no further treatment; the second had fresh lead acetate paper added every $24 \mathrm{hr}$.; the third had an additional $3 \mathrm{ml} . \mathrm{CCl}_{4}$ added daily. $\mathrm{H}_{2} \mathrm{~S}$ was evolved in the first and second sets after $48 \mathrm{hr}$. incubation and continued to be evolved for another $48 \mathrm{hr}$. $\mathrm{No}_{2} \mathrm{~S}$ was evolved from the third set during 7 days; after this time the daily additions of $\mathrm{CCl}_{4}$ were stopped and 2 days later $\mathrm{H}_{2} \mathrm{~S}$ was evolved.

In another experiment, as the amount of $\mathrm{CCl}_{4}$ was increased from 0.01 to $5 \mathrm{ml} . / 5 \mathrm{~g}$. soil the time for $\mathrm{H}_{2} \mathrm{~S}$ to be evolved increased from 1 to 3 days and the amount of $\mathrm{H}_{2} \mathrm{~S}$ increased too, as judged by the degree of darkening of the lead acetate paper. Thus it appeared that the $\mathrm{H}_{2} \mathrm{~S}$ was released after the $\mathrm{CCl}_{4}$ had evaporated. $\mathrm{H}_{2} \mathrm{~S}$ was evolved from heated soil, heated at $70^{\circ}$ for $\mathbf{1 ~ h r}$. whether or not $\mathrm{CCl}_{4}$ was added, but not from autoclaved soil. Thus it appeared that the effect of $\mathrm{CCl}_{4}$ on $\mathrm{H}_{2} \mathrm{~S}$ formation was similar to a partial sterilizing effect.

Inhibition of the $\mathrm{H}_{2} \mathrm{~S}$-producing Bacillus by other micro-organisms

Earlier experiments showed that $\mathrm{H}_{2} \mathrm{~S}$ evolution in soil could be inhibited by $\mathrm{CCl}_{4}$-sensitive micro-organisms (see Table 2 ). 
Isolation of inhibitory micro-organisms. In a preliminary experiment it was found that $B$. megaterium would not grow on SPP agar containing 1 part in 750,000 of crystal violet. The following experiment was planned to find whether the organisms which developed on crystal violet $\mathrm{SPP}$ agar were $\mathrm{CCl}_{4}$-sensitive. Two Rothamsted soil samples received sucrose $+\left(\mathrm{NH}_{4}\right)_{2} \mathrm{SO}_{4}$ solution and were incubated for 3 days; one sample also received $\mathrm{CCl}_{4}$. Crystal violet SPP and SPP agar plates were inoculated with $1 \mathrm{ml}$. of $1 / 10^{4}$ to $1 / 10^{8}$ dilutions of these soil samples. One lot each of crystal violet SPP and of SPP agar plates were flooded with $1 \mathrm{ml} . \mathrm{CCl}_{4}$ immediately after inoculation and another lot was left untreated. The duplicate plates were incubated at $30^{\circ}$ for $96 \mathrm{hr}$. The growths which resulted from the $1 / 10^{8}$ soil dilution is given in Table 3

Table 3. Growth of SPP agar and crystal violet SPP agar inoculated with $1 / 10^{8}$ dilutions of soils after various treatments

\begin{tabular}{|c|c|c|c|}
\hline $\begin{array}{c}\text { Initial treatment } \\
\text { of soil in addition } \\
\text { to sucrose }+ \\
\left(\mathrm{NH}_{4}\right)_{2} \mathrm{SO}_{4} \text { solution }\end{array}$ & Medium inoculated & $\begin{array}{l}\text { Treatment } \\
\text { given to } \\
\text { plate }\end{array}$ & Type of growth \\
\hline $\mathrm{CCl}_{4}, 1 \mathrm{ml}$ & SPP & $1 \mathrm{ml} . \mathrm{CCl}_{4}$ & $\begin{array}{l}\text { Large white to buff, smooth } \\
\text { and rough, shiny and dull, } \\
\text { opaque bacterial colonies. No } \\
\text { iridescent colonies. }\end{array}$ \\
\hline $\mathrm{CCl}_{4}, 1 \mathrm{ml}$. & Crystal violet SPP & $1 \mathrm{ml} . \mathrm{CCl}_{4}$ & No growth \\
\hline $\mathrm{CCl}_{4}, 1 \mathrm{ml}$ & SPP & None & $\begin{array}{l}\text { Large white buff, smooth, } \\
\text { rough, shiny, dull, opaque } \\
\text { bacterial colonies. Granular } \\
\text { iridescent colonies }\end{array}$ \\
\hline $\mathrm{CCl}_{4}, 1 \mathrm{ml}$ & Crystal violet SPP & None & No growth \\
\hline None & SPP & $1 \mathrm{ml} . \mathrm{CCl}_{4}$ & $\begin{array}{l}\text { White, buff, smooth, shiny, } \\
\text { dull, rough, opaque colonies } \\
\text { and granular iridescent } \\
\text { colonies }\end{array}$ \\
\hline None & Crystal violet SPP & $1 \mathrm{ml} . \mathrm{CCl}_{4}$ & No growth \\
\hline None & SPP & None & $\begin{array}{l}\text { Fungi, white, buff, opaque } \\
\text { colonies, large mucoid colonies } \\
\text { and non-granular, bluish, } \\
\text { iridescent colonies }\end{array}$ \\
\hline None & Crystal violet SPP & None & $\begin{array}{l}\text { Fungi, large mucoid, some } \\
\text { opaque bacterial colonies, also } \\
\text { bluish, iridescent colonies }\end{array}$ \\
\hline
\end{tabular}

The results for a given treatment were similar at all dilutions. The microorganisms which developed on crystal violet $+\mathrm{SPP}$ agar were $\mathrm{CCl}_{4}$-sensitive and the micro-organisms which were $\mathrm{CCl}_{4}$-resistant were crystal violet-sensitive. At the above dilutions there were no crystal violet-tolerant micro-organisms in soil treated with $\mathrm{CCl}_{4}$, whereas in the untreated soil there were some microorganisms which were sensitive and some which were tolerant to either crystal violet or $\mathrm{CCl}_{4}$. $\mathrm{CCl}_{4}$-sensitive bacteria were isolated from the crystal violet + SPP agar plate which received the $1 / 10^{8}$ dilution of untreated soil. The isolates 
were replated to test their purity and checked for $\mathrm{CCl}_{4}$ sensitivity in the following manner; SPP agar was plated with the isolate, flooded immediately with $1 \mathrm{ml}$. $\mathrm{CCl}_{4}$ and incubated, after the $\mathrm{CCl}_{4}$ had evaporated, for $72 \mathrm{hr}$. at $30^{\circ}$ and then examined for growth. Fungi were isolated from the $1 / 10^{4}$ dilution of the same soil on Czapek agar and tested for $\mathrm{CCl}_{4}$ sensitivity in the same way. In the above manner six cultures of $\mathrm{CCl}_{4}$-sensitive bacteria and four cultures of $\mathrm{CCl}_{4}$-sensitive fungi were obtained.

The effect of $\mathrm{CCl}_{4}$-sensitive micro-organisms on $\mathrm{H}_{2} \mathrm{~S}$ evolution by $\mathrm{B}$. megaterium. To determine whether these micro-organisms inhibited the evolution of $\mathbf{H}_{2} \mathrm{~S}$, $5 \mathrm{~g}$. samples of sterile Rothamsted soil were inoculated with a mixed suspension of $\boldsymbol{B}$. megaterium and the micro-organisms to be tested; some of the soil samples also received $\mathrm{CCl}_{4}$. A micro-organism was considered to be inhibitory when $\mathrm{H}_{2} \mathrm{~S}$ was evolved from the $\mathrm{CCl}_{4}$-treated soil but not from the untreated soil to which it had been added. The four fungi and six $\mathrm{CCl}_{4}$-sensitive bacteria were tested in this way against $\boldsymbol{B}$. megaterium; one fungus and three bacteria inhibited the evolution of $\mathbf{H}_{2} \mathrm{~S}$. The fungus was identified as a member of the genus Mucor, two of the inhibiting bacteria as species of Pseudomonas, and the other a species of Bacterium. One of the $\mathrm{CCl}_{4}$-sensitive bacteria which did not inhibit $\mathrm{H}_{2} \mathrm{~S}$ formation by $\boldsymbol{B}$. megaterium belonged to the genus Achromobacter, and the other two to the genus Aerobacter. Thus the inhibitory bacteria did not belong to the same species or even the same genus and not all the $\mathrm{CCl}_{4}$-sensitive bacteria inhibited the formation of $\mathrm{H}_{2} \mathrm{~S}$ by $\mathrm{B}$. megaterium.

An attempt was made to see whether the inhibition of $\mathrm{H}_{2} \mathrm{~S}$ evolution was due to an antibiotic effect of the fungus and one of the bacteria on the $B$. megaterium. Plates of sucrose $+\left(\mathrm{NH}_{4}\right)_{2} \mathrm{SO}_{4}$ medium were inoculated, either over the whole surface with a mixture of the test organism and $B$. megaterium or inoculated in straight lines with the inhibitory organism at right angles to the $B$. megaterium, and incubated for 5 days at $30^{\circ}$. No antagonism was observed on the plates inoculated by streaking. On the mixed inoculum plates the $\boldsymbol{B}$. megaterium formed slightly smaller colonies when grown in the presence of the bacterium as compared with the colonies of the pure culture of $B$. megaterium; the fungus showed no inhibition on the mixed plates.

The effect of phenol, formalin and ethanol on $\mathrm{B}$. megaterium and on the inhibitory micro-organisms. Phenol, formalin and ethanol are known to have a partial sterilizing effect when applied to soil, but in the experiment described earlier phenol, formalin or ethanol in the presence of water did not exhibit the same partial sterilizing effect as $\mathrm{CCl}_{4}$. To see what effect these substances had on $B$. megaterium and the inhibitory organisms, SPP agar plates were inoculated with these micro-organisms and flooded immediately after with $1 \mathrm{ml}$. of $2 \%$ phenol, $1 \%$ formalin or $95 \%$ alcohol, and examined for growth after 7 days' incubation at $30^{\circ}$.

The inhibitory bacteria and the fungi were killed by all three solutions, B. megaterium only by formalin. B. megaterium, however, failed to grow on SPP agar which contained $0.7 \%$ phenol or $30 \%(\mathrm{v} / \mathrm{v})$ ethanol in water. These results explained why phenol, formalin and ethanol solutions did not behave in the same way as $\mathrm{CCl}_{4}$. Formalin kills $B$. megaterium as well as the inhibitory 
micro-organisms; phenol and ethanol, however, because of their miscibility with water, remain in the soil, and although they do not kill the spores of $B$. megaterium they prevent their germination.

\section{DISCUSSION}

Previously the biological reduction of sulphate to $\mathrm{H}_{2} \mathrm{~S}$ has been associated with anaerobic conditions and the activities of anaerobic sulphate-reducing Desulphovibrio spp. The results of the present work show that sulphate can be reduced under well-aerated conditions by the aerobic Bacillus megaterium. From the fact that sulphide was produced in only one of a number of liquid media it would appear that to get a complete understanding of the activities of soil micro-organisms it is necessary to study their behaviour in soil as well as in laboratory media. The high sugar and $\left(\mathrm{NH}_{4}\right)_{2} \mathrm{SO}_{4}$ concentrations used in the experiments makes it unlikely that this type of reduction occurs to any marked extent in normal soils, but a study of reduction in the presence of other carbon and nitrogen sources might help in assessing its importance in nature.

The part played by $\mathrm{CCl}_{4}$ is one of partial sterilization. As a result of this, a number of different micro-organisms are killed, and amongst these are some which inhibit the evolution of $\mathrm{H}_{2} \mathrm{~S}$ by $B$. megaterium. These results indicate that in soil the type of reaction carried out by a particular micro-organism may depend, in part, on the types of accompanying micro-organisms; and that a number of processes normally not active in soil may become intensified as a result of the simplification of the soil microflora by partial sterilization. The way in which some of the $\mathrm{CCl}_{4}$-sensitive micro-organisms inhibit sulphate reduction by $\boldsymbol{B}$. megaterium is not known; no antibiotic effect could be demonstrated.

I wish to express my thanks to C.S.I.R.O., Australia, who made this research possible, to Dr H. G. Thornton, F.R.S., for criticism and advice, to Dr Mattingley for his help with radioactive sulphur and to Miss Mabel Dunkley for preparing the typescript.

\section{REFERENCES}

BaARS, J. K. (1930). Over Sulfaatreductie door bacteriën. 'Thesis, Delft.

Bunker, H. J. (1936). Review of physiology and biochemistry of the sulphur bacteria. Dep. Sci. Ind. Res., Chem. Res. Spec. Rep. no. 3.

Butlin, K. R., Adams, M. E. \& Thomas, M. (1949). The isolation and cultivation of sulphate reducing bacteria. J. gen. Microbiol. 3, 46.

Nadson, G. A. (1904). Bot. Zbl. 96, 591. Cited in Bunker, H. J. (1936).

Nastukoff, A. (1895). Essais sur le pouvoir reducteur des levures pures. Ann. Inst. Pasteur, 9, 766.

SawJalow, W. (1913). Über Schwefelwasserstoff-gärung im schwarzen Hulschlamme. Zbl. Bakt. (2 Abt.), 39, 440.

Shturm, L. D. (1948). Sulphate reduction by facultative aerobic bacteria. Mikrobiology, Moscow, 17, 415; abstract in Chem. Abstr. 43, 5448.

Shturm, L. D. (1950). Some observations on development of Vibrio desulfuricans in aerobic conditions. Mikrobiology, Moscow, 19, 289.

Smith, N. R., Gordon, R. E. \& Clark, F. E. (1946). Aerobic mesophilic spore formation bacteria. Misc. Publ. U.S. Dep. Agric. no. 559. 
Starkey, R. L. (1950). Relations of micro-organisms to transformation of sulphur in soils. Soil Sci. 70, 55.

Starkey, R. L. \& Wight, K. M. (1945). Anaerobic corrosion of iron in soil with particular consideration of the soil redox potential as an indicator of corrosiveness. New York: American Gas Association.

Tanner, F. W. (1918). Studies on the bacterial metabolism of sulphur. III. Formation of hydrogen sulphide from certain sulphur compounds by yeast-like fungi. J. Amer. chem. Soc. 40, 663.

Young, J. W. (1936). The bacterial reduction of sulphates. Canad. J. Res. B, 14, 49.

(Received 18 September 1952) 